\title{
A Global Empirical Evaluation of New Communication Technology Use and Democratic Tendency
}

\author{
Victoria Stodden \\ Berkman Center for Internet and Society \\ Harvard Law School \\ Cambridge, MA 02138 \\ vcsestanford.edu
}

\author{
Patrick Meier \\ Berkman Center for Internet and Society \\ Harvard Law School \\ Cambridge, MA 02138 \\ patrick.meieretufts.edu
}

\begin{abstract}
Is the dramatic increase in Internet use associated with a commensurate rise in democracy? Few previous studies have drawn on multiple perception-based measures of governance to assess the Internet's effects on the process of democratization. This paper uses perception-based time series data on "Voice \& Accountability," "Political Stability," and "Rule of Law" to provide insights into democratic tendency. The results of regression analysis suggest that the level of "Voice \& Accountability" in a country increases with Internet use, while the level of "Political Stability" decreases with increasing Internet use. Additionally, Internet use was found to increase significantly for countries with increasing levels of "Voice \& Accountability." In contrast, "Rule of Law" was not significantly affected by a country's level of Internet use. Increasing cell phone use did not seem to affect either "Voice \& Accountability", "Political Stability" or "Rule of Law." In turn, cell phone use was not affected by any of these three measures of democratic tendency. When limiting our analysis to autocratic regimes, we noted a significant negative effect of Internet and cell phone use on "Political Stability" and found that the "Rule of Law" and "Political Stability" metrics drove ICT adoption.
\end{abstract}

Index terms - cell phone, democracy, fixed effects model, ICT, internet

\section{INTRODUCTION}

Does the globalization of the Internet have a democratizing effect? The question has already been posed by numerous studies but these have largely taken the form of qualitative case studies and/or large theoretical analyses. In terms of a rigorous, quantitative establishment of the democratization effects of the Internet, however, the jury is still out [1]. At the heart of this debate, moreover, lies a more fundamental question about the essence of democracy. In fact, "unless we are clear about what democracy means to us, and what kind of democracy we envision, technology is as likely to stunt as to enhance the civic polity" [2]. The purpose of this paper is to contribute more rigorous data-driven analysis to the literature on Internet and democracy since "there is no doubt that rigorous and datadriven analysis of this relationship will benefit scholars and policymakers alike" [1].

Previous research on the topic of Internet and democracy can be characterized as lacking a serious perusal of the democracy and regime transitions literature. To be sure, "the trouble with the zealots of technology as an instrument of democratic liberation is not that they misconceive technology but that they fail to understand democracy" [2]. "In other words, "it turns out there is no simple general answer to the question: Is the technology democratizing?' until we have made clear what sort of democracy we intend." We address this question first before proceeding with a more detailed literature review.

Barber's notion of "strong democracy" comprises the careful and prudent judgment of citizens who participate in deliberative, self-governing communities. Schmitter and Karl write that, "modern political democracy is a system of governance in which rulers are held accountable for their actions in the public realm by citizens, acting indirectly through the competition and cooperation of their elected representatives"[3]. The two authors emphasize that citizens are the most distinctive element in democracies. "All regimes have rulers and a public realm, but only to the extent that they are democratic do they have citizens" [3]. In contemporary studies of democracy and particularly in pluralist theory, "a vibrant civil society is usually regarded as an essential for good governance and effective democratic consolidation" [4]. In other words, regular elections are not sufficient. As Zakaria noted, illiberal democracies have free elections but citizens remain cut off from real power due to the lack of civil liberties [5].

Huber et al. write that the most basic feature of democracy is power sharing [6]. They identify three clusters of power as primarily relevant for the chances of democracy: (1) the balance of power in civil society; (2) the balance of power between state and society; and (3) the transnational balance of power that shape the first two and constrain political decisionmaking. By remaining diverse and independent of the state, political participation by civil society acts as a channel of public voice and accountability, and a way of challenging and checking the unbridled power of authoritarian regimes [4]. The structure of state-society relations is equally relevant for democracy. As Huber et al. note, "the power of the state needs to be counterbalanced by the organizational strength of 
the civil society to make democracy possible; the state must not be so strong and autonomous from all social forces as to overpower civil society and rule without accountability." Clearly then a governing body that fails to follow the "rule of law," should not be considered democratic [3]. These elements of democracy are not sufficient conditions for a stable democracy, but they are necessary and indispensable to the persistence of democratic governance.

The italicized terms above represent the fundamentals behind the sort of democracy we intend: active citizen participation, good governance, accountability, power sharing, balance of power and rule of law. The few quantitative studies that do exist on Internet and democracy tend to aggregate these fundamentals of democracy into a single index. Doing so means these lose important information on how these individual components of democracy may be affected by the growing prevalence of global Internet access. Furthermore, past quantitative and qualitative studies tend to focus primarily on the impact of the Internet on established democracies. They also focus on the 1990s almost exclusively, a serious limitation that remains surprisingly understated in the literature. Equally problematic in the current literature is the interchangeable use of the terms "Internet" and "information revolution." The terms are purposefully not differentiated on the basis that the predominant feature of the information society is the spread of the Internet. While this is true of Western democracies, it is certainly not true for the majority of developing, nondemocratic countries, where cell phones are the most widely spread communication technology after radios [7]. Indeed, the irony is that "those who might most benefit from the net's democratic and informational potential are least likely to have access to it, the tools to gain access, or the educational background to take advantage of the tools" [2].

This paper seeks to redress each of these shortcomings. First, since the boundaries of the term "democracy," and how it is measured, is subject to lively debate, we use multiple perception-based measures of governance for our dependent variables. Governance indicators provide a better set of proxies for the sort of democracy we intend as identified above. We therefore draw on the following three World Bank indicators: (1) Voice and Accountability (VA) measuring perceptions of the extent to which a country's citizens are able to participate in selecting their government, as well as freedom of expression, freedom of association, and a free media; (2) Rule of Law (RL) measuring perceptions of the extent to which agents have confidence in and abide by the rules of society, and in particular the quality of contract enforcement, property rights, the police, and the courts, as well as the likelihood of crime and violence; and (3). Political Stability and Absence of Violence (PS) measuring perceptions of the likelihood that the government will be destabilized or overthrown by unconstitutional or violent means, including politically motivated violence and terrorism. These metrics are drawn from the World Bank Governance Indicators Research Database (see http://info.worldbank.org/governance/wgi/).

Second, we draw on data from 2000 through 2006, a time when Internet access and cell phone use is significantly more prevalent and globalized than in the 1990s. If a statistically significant relationship between Internet and democracy does exist, then it is more likely to manifest itself now and not in the 1990s. Third, we draw on both Internet and cell phone data per 100 inhabitants per 181 countries to assess the impact of the information revolution on democratization. We use regression analysis to determine whether Internet or cell phone use has had a correlative effect on measures of democratic tendency. We also model whether the collection of democratic measures has had a correlative effect on Internet or cell phone use.

The paper is structured as follows: the first section reviews the current debate and literature on Internet and democracy. The second section explicates the datasets used in this study while the third section formalizes the statistical models employed in the regression analysis. Section four reviews the results and provides an interpretation of the findings. The fifth and final section concludes the study.

\section{LiterATURE REVIEW}

The Internet and democracy literature comprises two distinct schools of thought each comprising a host of qualitative research and some quantitative inquiry. In this section we review in some detail the qualitative and quantitative literatures that have contributed to both schools of thought over the past ten to fifteen years. In so doing, we compare and contrast the main arguments along with the respective findings. As noted in the introduction, one common shortcoming of the Internet and democracy literature is the tendency to oversimplify our understanding of democracy. The purpose of this literature review is thus to redress this gap evident in previous studies.

The first school of thought is often referred to as the more populist school of thought. This strand of the literature subscribes to the viewpoint that the Internet has democratic relevance and impact [8], [9], [10], [11]. According to these authors, the Internet will decentralize access to communication and information while increasing citizen access [12]. Best and Wade write that "the Internet's collective characteristics (e.g., low cost, multidirectional capability, etc.), helps make this possible." We first review the qualitative literature that comprises this school of thought followed by quantitative studies.

Dahl previously observed that telecommunications technologies have a key role in making possible the advanced democratic country, where policy is firmly anchored in the judgment of the "demos" [13]. In his list of the procedural minimal conditions that must be present for modern political democracy to exist, Dahl thus argues that citizens should have the right to seek out alternative sources of information. Rheingold has dubbed the Internet as "the great equalizer" because it can "equalize the balance of power between citizens and power barons" [14]. The idea here "is that the Internet will serve as a mass audience, and will politicize them in the process" [12]. Anderson et al. draw on sociological research to show that electronic networks lead to the "break-down of status-based social structures" and "increased participation in 
discussion, decision-making, and task processes by those who typically are political or economically disadvantaged" [15]. Etzioni sees in the Internet the possibility of an advancement of the state of public affairs through "teledemocracy" [16].

Other scholars claim that the Internet will "enable a Jeffersonian revolution" [17]. Grossman argues that a "third epoch of democracy is arriving by the hand of technology," and claims that a "new, hybrid electronic republic' is now forming to displace the creation of Montesquieu, Locke, Madison and their contemporaries" [18], [12]. The practice of "electronic democracy," according to Browning, will differ substantially from previous renderings of democracy [19]. Perhaps the most provocative claim associated with this more populist school of thought is the one made by Negroponte, who argues that the nation-state will evaporate as a consequence of the information revolution [20]. Snider suggests that citizens need only be potentially informed in order to hold government accountable [21].

Barber opines that by favoring decentralization, the multiplication of choice, and consumer sovereignty, new technologies such as the internet or cell phone have already, albeit inadvertently, benefited democratic political culture [2]. According to Barber, "democracy is a form of government that depends on information and communication. It is obvious then that new technologies of information and communications can be nurturing to democracy. They can challenge passivity, they can enhance information equality, they can overcome sectarianism and prejudice, and they can facilitate participation in deliberative political processes." Hill and Hughes argue that those who subscribe to the populist school have reasons to be optimistic: "If the mere fact that political discourse against repressive governments is taking place is a good in itself, then the utopians have reason to celebrate [22]. Perhaps the Internet will bring about a wider democratic revolution in the world" [22].

Bimber is more cautious, arguing that while the Internet is accelerating the process of issue group formation and action (in America), the structure of political power has not been revolutionized or qualitatively transformed into a new epoch of democracy [12]. According to Bimber, other scholars believe that the Internet has a "transformative potential" because it facilitates a kind of "one-to-one interaction among citizens and between citizens and government." Along these lines, some scholars such as Corrado and Firestone write that the Internet has the potential to promote "unmediated" communication and thereby decrease citizens' reliance on officials and organizations [23]. In sum, what distinguishes the populist enthusiasm for the Internet is the "idea that elites and political intermediaries will grow less important" [12].

In the more contemporary, qualitative literature, Steele and Stein, argue that the Internet amplifies trends in international relations [24]. Rosenau and Johnson address the impact of the Internet at both the individual and international level [25]. At the individual level, the authors argue that the Internet can be used as a tool to organize collectively to effect social and political change around the world (see http://www.DigiActive.org, for example). At the international level, the authors make the bold claim that the Internet has "contributed to the rise of a more multicentric world structure in which nation-states have seen their preeminence lessen and non-governmental actors take the stage" [1]. The salient point here is that groups and individuals can far more efficiently form coalitions of consequence with a range of powerful collectives. As Best and Wade rightly note, there are obvious democratic elements to this, including the need for "nation-states to provide democratic rights to their citizens so as to build legitimacy on the global stage" [1].

We now turn to the quantitative studies that comprise the first school of thought. One of the earlier statistical studies on this side of the literature was carried out by Kedzie, who provides an account of how information communication technologies contributed to the "third wave" of democracy [26]. Prior to the fall of the Soviet Union and the proliferation of new democracies in Eurasia, the mainstream theory of democratization held that democracy followed economic growth and development [27]. To be sure, one of the few robust findings in the literature is that democracy is more likely in more developed countries [28], [29], [30]. Longdregan and Poole have also shown that the most significant predictor of transitions to authoritarianism is poverty [31], [32]. "In short, after 20 years of observation and analysis during the third wave of academic interest in democratization, we can be reasonably certain that a positive relationship between development and democracy exists, though we do not know why" [33].

Kedzie, however, was more interested in testing another potential causal mechanism, the "dictator's dilemma" hypothesis, which suggests that the globalization of markets places pressure on authoritarian regimes to keep their countries' communication borders open. He reasoned that the ensuing massive flow of information would not only allow for "the efficient passage of commercial information, but also for more 'democratic' information" [1]. As Bimber observes, the most important predictions about the Internet's impact on politics amount to "causal claims regarding the effect of information flow on political participation and the organization of interests" [12]. Other scholars have made related arguments. Webster, for example, writes that the Internet has helped to facilitate a new form of capitalism called "information capitalism" in which global labor markets require highly flexible workers who continuously adapt and learn [34]. Regimes that impose restrictions on information capitalism forgo the financial returns possible by tapping into the information economy [35], [36], [37].

In his study, Kedzie employs regression analysis to compare how much of the variation in democracy is explained by both traditional predictors of democracy and the strength of Internet diffusion by drawing on data from 144 countries [26]. For his set of control variables, Kedzie included more traditional predictors of democracy including economic development, education, human development and health. He also included indicators of pre-Internet information communication technologies (ICTs). His results suggest that the Internet is indeed 
a strong predictor of democracy, more so than traditional determinants of democracy. In a follow up study, Richards assessed the relationship between the Internet and physical integrity [38]. His findings support Kedzie's. However, the latter study faces an important limitation since Kedzie's (rather simple) longitudinal analysis draws on data from 1993. At this point during the early 1990s, the Internet was hardly globalized.

Best and Wade recognize this important short coming in Kedzie's study and therefore explore the global effect of the Internet on democracy over a ten year period, 1992-2002 [1]. They aggregate political and civil rights data from Freedom House to formulate a democracy index, which serves as their dependent variable. The number of Internet users per 1,000 represents their independent variable while the following measures are used as control variables: GDP per capita, education and literacy rates, life expectancy, urbanization, prevalence of non-Internet ICTs. Their analysis shows that a statistically powerful correlation exists between Internet diffusion and level of democratization. "The more salient observation to make, however, is that while economic prevalence and literacy maintain relatively constant correlations with democracy, the correlation for Internet prevalence gradually strengthens, almost to the same level as economic prevalence" [1].

The authors suggest that this dynamic reflects the growing significant relationship between Internet prevalence and democracy: "perhaps this is an indication that the Internet has come of age as a correlate of democracy" [1]. Indeed, they posit that this growth in correlation strength might "be expected given the positive network externalities, the network effect' that is a salient property of the Internet" [1]. However, the coefficients from the regression analysis reveal that Internet usage is only able to predict a minimal amount of the variation in democracy: "to generate one point of democracy, an extra 500 Internet users per 1,000 citizens is needed, or an extra $\$ 5,882$ of GDP per capita is needed" [1]. The scale of democracy runs from 2 to 14 . In terms of democracy's traditional determinants, GDP was a weak predictor while literacy turned out to have no significance whatsoever. The other control variables used were either insignificant or internally correlated.

While Best and Wade's important contribution to the literature on Internet and democracy is one of the few contemporary quantitative studies carried out thus far, their approach does face a number of important limitations [1]. For one, their democracy index needs to be unpacked and "its constituent components, such as freedom of the press, openness of the electoral process," for example, tested against traditional determinants of democracy to determine whether one component provides more explanatory power than others. Another limitation of their data is the fact that it extends only to 2002. This should be updated today due to the rapid pace of ICT diffusion over the past several years. In addition, several scholars have criticized the Freedom House data with regards to conceptualization, measurement and aggregation issues (Munck and Verkuilen, 2002; Rydland et al., 2008). Furthermore, as discussed subsequently, there is little to no variation in the Freedom House data, which makes meaningful statistical analysis more difficult.

In contrast to the populist literature, the second school of thought disputes the majority of claims that exist vis-à-vis the relationship between Internet and democracy. The counterarguments are based on both qualitative and quantitative research. In terms of qualitative research, several scholars argue that the Internet is merely an extension of the ruling class and centralized control [39], [40], [41], [34], [42]. According to Neuman, even if the increase of ICTs had led to an increase in the motivation to communicate - which he argues has not happened - then ICTs would have become centralized by government turning them into social control mechanisms [43]. Scholars who subscribe to this school of thought maintain that mass media information technologies discourage collective behavior, "unless the rise in couch potatoes can be considered a social movement" [44], [45], [46].

In contrast to Snider's argument about the mere potential of citizens being informed acting as a source of accountability, if power is measured by the potential for "monopoly and control over information and communication, it is evident that the new technology can become a dangerous facilitator of tyranny" [21], [2]. Indeed, while the Internet may enable citizens to subvert political hierarchy, Barber notes that with increased participation comes the peril of political and economic surveillance. The populist school of thought is often blind to "how easily liberating technologies become tools of repression" [2].

Bimber rejects the supposition that the Internet will have significant effects on public life, point out that "both theory and empirical evidence cast grave doubt on the communication-action connection at the core of the populist theory" [12]. Lippmann argued that the capacity of ICTs to recreate politics is constrained by human nature, ie. cognitive processing, and not by the technical properties of the media themselves [47]. The Internet, then, is no different than other ICTs even if the new medium differs from previous technologies in a fundamental way, namely allowing social bonding to occur asynchronously. In sum, the Internet is "hardly producing the first dramatic expansion in communication: telephone, radio, and television also expanded communication profoundly." There seems no compelling reason to believe that the communication capacity of the Net will have such a dramatically different effect than have other advances in pointto-point and broadcast communication" [12]. Moreover, Page argues, new ICTs may very well overcome spatial distance but his far from sufficient for establishing vibrant forms of political communication and deliberation [48].

Furthermore, "if democracy is to be understood as deliberative and participatory activity on the part of responsible citizens, it will have to resist the innovative forms of demagoguery that accompany innovative technology and that are too often overlooked by enthusiasts [2]. Aristotle wrote that the basis of a democratic state is liberty. Barber adds that a "free society is free only to the degree that its citizens are informed and that communication among them is open and informed [2]. However, recent research and empirical work 
confirms that governments increasingly have the upper hand in controlling and regulating the impact of the information revolution [49], [50], [51], [52], [53], [54], [55], [56], [57], [58]. As Goldsmith observes, "if governments can raise the cost of Net transactions, they can regulate the transactions" [59]. Beilock and Dimitrova found that countries with lower Freedom House scores for civil liberties had significantly lower Internet usage (even when controlling for economic development) [60].

De Mesquita and George Downs also argue that government elites (e.g., in Singapore) have learned to "stifle the bottom-up democratic potential of the Internet and still promote economic growth, contrary to Kedzie's dictator's dilemma argument" [61]. As Bimber notes, the "central theoretical problem for the populist claim is the absence of a clear link between increases in information and increases in popular political action" [12] To this end, McLuhan's old dictum may be wrong: "the medium is not the whole message. Content matters, and there is simply no overwhelming reason to believe that a new medium will necessarily enhance the political quality of communicative content" [12]. In short, "technology need not inevitably corrupt democracy, but its potential for benign dominion cannot be ignored" [2].

In terms of quantitative analysis, Scheufele and Nisbet's 2002 statistical study suggests that the Internet does not increase democracy. "Through linear regression, they find that mass media broadcasting (e.g., television, newspapers) plays a far more effective role than the Internet in promoting democratic citizenship" [1], [62]. Given that an established body of quantitative research on this topic has yet to materialize, Scheufele and Nisbet do caution against generalizing the results of their study, which focused exclusively on the United States. Other scholars interested in this line of research have questioned the supposed direction of causation drummed up by the populist school of thought. Using multiple measures of regime type, Milner's statistical analysis demonstrates that, ceteris paribus, democracies permit much greater online access, both in terms of Internet users per capita and Internet hosts per capita [63]. To this end, the information revolution may merely be reinforcing pre-existing dynamics.

Milner's study uses data from $1991-2001$ to measure the influence of regime type of adoption of the internet. This study attempts to address a slightly different question-whether there is a relationship between measures of democracy and ICT penetration-but we build on her work by extending the range of years to 2006 (although we begin measurement in 2000). We adopt a fixed effect model and control for the time component directly in the model.

Beilock and Dimitrova develop a model to explain global country differences in Internet use using income, measures of freedom, region dummies, and development indices [60]. Their data is a cross section from 2001 and does not take democratic variables directly into account.

Best and Wade ask the question closest to that addressed in this paper [1]. They ask whether Internet penetration has an effect on the level of democracy in a country. Their study is global in scope and uses time series data from 1992 to 2002. We seek to build on their work by using data from 2000 to 2006 and using the World Bank Governance metrics as our measures of democratic tendency. Best and Wade combined the Freedom House metrics of political rights and civil liberties as their measure of democratic tendency. As described subsequently we feel the Freedom House data are not well suited to a regression study such as this one.

\section{A. Our Approach to Measuring Democratic Tendency Using the World Bank Governance Indicators}

Dahl characterizes a government with power vested in a plurality as follows [13]:

1) Control over governmental decisions about policy is constitutionally vested in elected officials.

2) Elected officials are chosen and peacefully removed in relatively frequent, fair and free elections in which coercion is quite limited.

3) Practically all adults have the right to vote in these elections.

4) Most adults also have the right to run for the public offices for which candidates run in these elections.

5) Citizens have an effectively enforced right to freedom of expression, particularly political expression, including criticism of the officials, the conduct of the government, the prevailing political, economic, and social system, and the dominant ideology.

6) They also have access to alternative sources of information that are not monopolized by the government or any other single group.

7) Finally, they have an effectively enforced right to form and join autonomous associations, including political associations, such as political parties and interest groups, that attempt to influence the government by competing in elections and by other peaceful means.

The first four points largely describe procedural aspects of a democracy, whereas the last three points delineate the communication aspect necessary for a well-functioning democratic regime. In fact, Diamond goes further and notes that "[s]ome insist on a fairly robust (though still procedural) definition of democracy, like Dahl's 'polyarchy.' By this conception, democracy requires not only free, fair, and competitive elections, but also the freedoms that make them truly meaningful (such as freedom of organization and freedom of expression), alternative sources of information, and institutions to ensure that government policies depend on the votes and preferences of citizens" [64]. Expanding on Dahl, Diamond has developed his own list of characteristics of a democracy [65]:

1) Control of the state and its key decisions and allocations lies, in fact as well as in constitutional theory, with elected officials (and not democratically unaccountable actors or foreign powers); in particular, the military is subordinate to the authority of elected civilian officials.

2) Executive power is constrained, constitutionally and in fact, by the autonomous power of other government in- 
stitutions (such as an independent judiciary, parliament, and other mechanisms of horizontal accountability).

3) Not only are electoral outcomes uncertain, with a significant opposition vote and the presumption of party alternation in government, but no group that adheres to constitutional principles is denied the right to form a party and contest elections (even if electoral thresholds and other rules exclude small parties from winning representation in parliament).

4) Cultural, ethnic, religious, and other minority groups (as well as historically disadvantaged majorities) are not prohibited (legally or in practice) from expressing their interests in the political process or from speaking their language or practicing their culture.

5) Beyond parties and elections, citizens have multiple, ongoing channels for expression and representation of their interests and values, including diverse, independent associations and movements, which they have the freedom to form and join.

6) There are alternative sources of information (including independent media) to which citizens have (politically) unfettered access.

7) Individuals also have substantial freedom of belief, opinion, discussion, speech, publication, assembly, demonstration, and petition.

8) Citizens are politically equal under the law (even though they are invariably unequal in their political resources).

9) Individual and group liberties are effectively protected by an independent, nondiscriminatory judiciary, whose decisions are enforced and respected by other centers of power.

10) The rule of law protects citizens from unjustified detention, exile, terror, torture, and undue interference in their personal lives not only by the state but also by organized nonstate or anti-state forces.

Like Dahl, Diamond includes procedural aspects of a democratic regime (points one through three) and he enshrines what he considers essential communication requirements in points four through seven. These latter points can be characterized as approximating a "freedom of expression" or "political voice" aspect to democracy. We found the World Bank governance metric of "Political Voice and Accountability" to represent Diamond's notion well in that it measures "perceptions of the extent to which a country's citizen's are able to participate in selecting their government, as well as freedom of expression, freedom of association, and a free media" [66]. Like all the World Bank Governance metrics, it was built from surveys and other sources of data within each country. These sources give an idea of "freedom of belief, opinion, discussion, speech, publication, assembly, demonstration, and petition" present in the country, although they do not measure the proliferation of channels of communication that Diamond enunciates. The World Bank governance indicators metrics are based on 35 data sources some of which yield "subjective or perceptionsbased data" including that from "household and firm survey respondents, as well as thousands of experts working for the private sector, NGOs, and public sector agencies" [66].

In points eight through ten, Diamond gives a description of the role of law in a democracy. The World Bank has a governance metric that expresses some of this: "measuring perceptions of the extent to which agents have confidence in and abide by the rules of society, and in particular the quality of contract enforcement, property rights, the police, and the courts, as well as the likelihood of crime and violence" [66]. This approximates the World Banks "Rule of Law" metric and we propose it as an empirical measure of Diamond's points eight through ten.

The World Bank also has a metric measuring political stability: "perceptions of the likelihood that the government will be destabilized or overthrown by unconstitutional or violent means, including politically-motivated violence and terrorism" [66]. While not enumerated in either Diamond's or Dahl's lists, Amartya Sen postulated an empirical correlation between democratic regimes and political stability [67]. He notes both the "political incentives provided by democratic governance" to prevent crises and specifically that the "positive role of political and civil right applies to the prevention of economic and social disasters in general" [67]. Thus we investigate the World Banks "Political Stability" metric as another measure of democratic tendency.

In measuring the relationship between ICT penetration and these democratic variables, it is clear that country wealth is a confounding factor that sound be taken into account: wealthier countries are both more likely to be democratic and to be the heavier users of both the Internet and the cell phone. We gathered gross domestic product (GDP) data from 2000 to 2006 from the International Monetary Fund. The GDP data is purchasing parity adjusted to be directly comparable between countries.

Diamond notes that country size is highly correlated with regime type: "countries with populations under one million are much more likely to be both democracies and liberal democracies. Two-thirds of these countries are liberal democracies, while only 30 percent of countries with populations over one million are. Among the larger 150 countries, only half are democracies, while 70 percent of the small countries are. The countries with populations over one million are about twice as likely as small states to have an electoral authoritarian regime and half again as likely to have a closed authoritarian regime." [64], [65]. Because of this, we included population in our models to control for country size. The population data for 2000 to 2006 was also gathered from the IMF. ${ }^{1}$

\section{B. Limitations of The Data}

The ICT data is gathered from the International Telecommunications Union (ITU). The ITU requested the number of Internet and cell phone users from each country. This raises a host of questions about the reliability of the data since it

\footnotetext{
${ }^{1}$ Both the IMF GDP and population data are available at http://www.imf. org/external/pubs/ft/weo/2008/01/weodata/
} 
is self-reported by the country. Perhaps the country has an incentive to under or over-report? It is plausible that some countries have more reliable data collection mechanisms in place than others. With one report per country per year, the data are highly granular, but they do seem to follow steady trends, and steadily upwards in ICT adoption.

The World Bank did not calculate governance metrics for 2001. We carried out simple linear interpolation to provide a data point for each country in this year. We made the decision to do this since there are only six time points from which to interpolate, and only one, the year 2000, falls before our missing data. This creates data that are "too smooth" for year 2001 since they have been created from our pre-existing data and this will make our results appear more precise than they in fact are. We argue that this effects is minor since the World Bank data are themselves aggregated from a large number of sources, and thus less subject to noise than using a single source would be.

Other metrics of the level of democratic rights exist, such as the Freedom House "Freedom in the World" metric. Freedom House carries out an annual global survey of political rights and civil liberties. We choose not to use this as a measurement of democratic tendency for two reasons. We felt that the World Bank Governance Indicators could be well grounded in the theory of democracy as measures of democracy. Secondly, the Freedom House measures have some quantitative limitations. A certain amount of inertia is built into the measurements so that it is difficult for a country to move much from one year to the next. For both political rights and civil liberties a country is scaled from 0 to 7 , giving only 8 possible outcomes for a country. Combining these two factors leads to a database that does not shift very much from year to year. In the years of our study, 2000 to 2006, of the 193 countries surveyed by Freedom House (after subtracting the 9 with missing values for both political rights and civil liberties for the entire time series), 105 had no change in their scores for political rights and 86 had no changes in their civil rights scores. The average variance of those that did exhibit some change from 2000 to 2006 was 0.48 for political rights and 0.32 for civil liberties. This means the majorities of countries, if they changed at all, changed by perhaps one point on the 8 point scale.

Having more years of data, including 2007, would improve our modeling. At the time of this writing, the World Bank Governance metrics were not available for 2007 .

The IMF estimated some of the population number for some of the countries. It is likely this has the effect of providing population data that is smoother than it would otherwise be. Note also that both ICT measures, the Internet and Cell Phone use, are measures per 100 inhabitants. We emphasize that this must be carefully noted in interpretation of the regression results, since we use population as an independent variable. We also note that even though the ITU collects Internet use statistics for each country, what it really means to use the Internet can vary by country due to filtering, censoring, and other restrictions on access. The OpenNet Intiative at the Berkman Center for Internet and Society monitors the filtering activity for 40 of the countries most actively engaged in repressing internet activity [68], [69]. Although not as extreme as the case of the Internet, cell phone use can be restricted by the government as well, and will differ from country to country. Zuckerman gives several examples of government crackdowns on mobile phone use: Belarus's reported shutdown of their SMS network in March 2006, reports of Ethiopian cell phone blocking during the 2005 election protests, and Cambodian blocking of SMS for two days before their 2007 elections [7].

North Korea and Cuba were dropped from the study since official data is not reported for these countries. It is generally known that there is very little internet access in Cuba, and little to none in North Korea and these are both regimes with little democracy. If we had been able to include these countries in our estimation of the models, this would likely have bolstered our results. ${ }^{2}$ Details of the data cleaning and amalgamation process are on the study website at http://www.stodden.net/ ICTD.

Our population data was obtained from the International Monetary Fund and contains a sparse number os missing values. The IMF has made estimates of their missing data to complete the dataset. ${ }^{3}$

\section{EMPIRICAL MODELING}

Our data comprises a panel containing $N$ different times series each consisting of $T$ observations. The number of countries, $N$, is 181 , and $T$, the number of years in our study, is 7. A fixed effects model of our democratic measures' effect on ICT penetration follows:

$$
\begin{gathered}
I C T_{i t}=\beta_{0}+\beta_{1} R L_{i t}+\beta_{2} V A_{i t}+\beta_{3} P S_{i t}+ \\
\beta_{4} P O P_{i t}+\beta_{5} G D P_{i t}+\beta_{6} M F_{i t}+ \\
\gamma_{t} T D+\xi_{i} C D+\epsilon_{i t} \\
i=1, \ldots, N, t=1, \ldots, T .
\end{gathered}
$$

In this paper we model the penetration of Internet or cell phone usage per 100 inhabitants, $I C T$, as a function of the World Bank democratic measures (Rule of Law, Voice and Accountability, and Political Stability $)^{4}$, country size, country wealth, and the male/female ratio in the country.

$I C T$ is one of "Internet Use" or "Cell Phone Use."5 GDP is the per capita Gross Domestic Product for country $i$ at year $t$, adjusted for purchasing power parity. ${ }^{6} P O P_{i t}$ is the

\footnotetext{
${ }^{2}$ Countries with missing values also tended to support our hypothesis: Afghanistan, Bhutan, Comoros, Kiribati, Serbia, St. Kitts and Nevis, TimorLeste, and Tonga. Cuba, Iraq, Montenegro, and North Korea simply did not furnish enough data for inclusion in the study.

${ }^{3} \mathrm{~A}$ precise explanation of their data interpolation procedure was not readily available. See http://www.econstats.com/weo/V023.htm

${ }^{4}$ Available at http://info.worldbank.org/governance/wgi/

${ }^{5}$ The data used in this study is available at http://www.itu.int/ITUD/ict/informationsharing/

${ }^{6}$ The data are available at http://www.imf.org/external/pubs/ft/weo/2008/01/weodata/index.aspx
} 
population of country $i$ at year $t$ and $M F_{i t}$ is the male/female gender ratio. $^{7}$

$\beta_{0}$ is the intercept term for country $i$, and $\gamma_{t} T D$ and $\xi_{i} C D$ are a time effect and a country effect, respectively. The effect of time is controlled for by dummy variables: $T D_{t}$ is 1 for year $t$ and 0 otherwise. Similarly $C D_{i}$ is a dummy variable that is 1 for country $i$ and 0 otherwise, controlling for the differences between countries. Finally, $\epsilon_{i t}$ is a disturbance term with distribution $N\left(0, \sigma_{i}^{2}\right)$, which we assume to be uncorrelated across country cross sections. In this study there are $N=181$ countries and $T=7$ years.

\section{A. Autocorrelation in Panel Data}

A panel regression model of this type is subject to possible autocorrelation between subsequent observations because of the time series components. In a regression model as described above, it is possible to 'discover' what Granger and Newbold [70] termed "spurious" relationships between the variables. That is, tests of significance on estimated coefficients may indicate a significant result, when in fact none is present. Granger and Newbold suggest economic time series data may be especially prone to autocorrelation since they tend to be non-stationary, in that it is not uncommon for the process generating the data to depend on the time it was sampled. For example, economic time series are commonly subject to seasonal or cyclical effects. Time series data that are not stationary will violate the assumptions of least squares regression since the variance of the error term will depend on time and thus introduce a bias into coefficient estimation. ${ }^{8}$ Granger and Newbold describe a high $R^{2}$ value and a low Durbin-Watson statistic as warning signs that the estimated model may be yielding spurious results.

Thus it is important to determine whether the time series data in this study are nonstationary. Our data are sampled yearly suggesting they may avoid annual cyclical effects. We analyze 181 countries from 2000 to 2006 (with 2001 interpolated for the World Bank variables) and thus have 7 values in each time series. As Granger and Newbold mention, finely sampled time series tend to exacerbate the cyclical effects and thus nonstationarity in the data.

As is typical, the Augmented Dickey-Fuller test was used to assess nonstationarity in each of our time series. Since Internet and Cell phone use are increasing rapidly for the vast majority of the countries in our study, we measured the autoregressive structure of each time series as stationary around a trend line, and modeled with one lag. The null hypothesis is that the data are nonstationary. The test was applied to the ICT and World Bank data at the country level. For the Internet and mobile phone data the test rejected the null hypothesis of nonstationarity for 40 and 35 of 181 countries respectively, meaning that for around $20 \%$ of the Internet and cell phone penetration time series, nonstationarity is not evident. ${ }^{9}$. When

\footnotetext{
${ }^{7}$ The gender ratio data was obtained from the Census Department's International Database at http://www.census.gov/ipc/www/idb/tables.html

${ }^{8}$ For a mathematically precise explanation see [70], p. 2.

${ }^{9}$ The tests were performed at the $10 \%$ level
}

the same test was performed on the World Bank variables, 54 , 62 , and 60 of 181 rejected nonstationarity for Rule of Law, Voice and Accountability, and Political Stability, respectively (about one third of the data). Although there some evidence of stationarity, it appears that the majority of the time series included in this study are nonstationary, and it's potential biasing of coefficient estimates is a concern. ${ }^{10}$ The typical remedy is the difference the data to remove the nonstationarity.

Running the regressions in the above equation allowed us to carry out tests on the residuals directly to evaluate the level of autocorrelation. There are two regressions to be run in this study, modeling Internet penetration and cell phone usage. Typically the Durbin-Watson test with one lag is used to test for autocorrelation in the structure of the regression residuals and the regression with Internet use as a dependent variable was found to have autocorrelation present, and the cell phone penetration regression was not, with Durbin-Watson values of 1.86 and 2.01 respectively. ${ }^{11}$

The Durbin-Watson statistic is created by calculating $d=$ $\frac{\sum_{t=2}^{T}\left(\epsilon_{t}-\epsilon_{t-1}\right)^{2}}{\sum_{1}^{t} \epsilon_{t}^{2}}$, where $\epsilon_{t}$ is the $t$ th residual from the regression. It follows that $0<d<4$. A value of 2 indicates no autocorrelation. To test whether the Durbin-Watson test statistics could be considered equivalent to 2 , the test in the $R$ statistical software package was used [71].

The adjusted $R^{2}$ values were 0.9246 and 0.9199 , seeming to fit the Internet regression squarely into Granger and Newbold's area of caution: a low Durbin-Watson statistic and a high $R^{2}$ value, and also casts some suspicion on the cell phone regression. Granger and Newbold offer that until "a really satisfactory procedure is available, we recommend taking first differences of all variables that appear to be highly autocorrelated." (p. 8.) We carried out this operation on both the Internet and cell phone use regressions because of the high $R^{2}$ values and the nonstationary data in both regressions, even though the Durbin-Watson statistic did not suggest autocorrelation among the cell phone regression errors. The plots of the residuals for both regressions indicate possible heteroskedasticity. This suggests running the following differenced model:

$$
\begin{gathered}
\Delta I C T_{i t}=\beta_{0}^{\prime}+\beta_{1}^{\prime} \Delta R L_{i t}+\beta_{2}^{\prime} \Delta V A_{i t}+\beta_{3}^{\prime} \Delta P S_{i t}+ \\
\beta_{4}^{\prime} \Delta P O P_{i t}+\beta_{5}^{\prime} \Delta G D P_{i t}+\beta_{6}^{\prime} \Delta M F_{i t}+ \\
\gamma_{t}^{\prime} T D+\xi_{i}^{\prime} C D+\epsilon_{i t} \\
i=1, \ldots, N, t=2, \ldots, T .
\end{gathered}
$$

Running this model for differenced Internet penetration and differenced mobile phone use did not improve the Durbin-

\footnotetext{
${ }^{10}$ Note that a combination of nonstationary time series may in fact be stationary. This is termed cointegration.

${ }^{11}$ The p-values for the Durbin-Watson test are generated via a bootstrapping method and can fluctuate. In this case the p-values were 0.022 for the Internet regression and 0.962 for the cell phone regression.
} 
TABLE I

SUMMARY STATISTICS FOR 2000 DATA

\begin{tabular}{|lrrl|}
\hline Variable & Mean & Min & Max \\
\hline Internet Use per 100 & 7.25 & 0 & 45.58 \\
Cell Use per 100 & 16.02 & 0 & 81.73 \\
\hline Rule of Law & -0.07 & -2.02 & 1.95 \\
Voice \& Accountability & -0.06 & -2.05 & 1.67 \\
Political Stability & -0.08 & -2.73 & 1.54 \\
\hline GDP (PPP per capita) & $8,998.10$ & 229.36 & $55,248.25$ \\
POP (millions) & 33.20 & 0.04 & 1267.43 \\
Gender Ratio (M/F) & 100.4 & 85.3 & 212.3 \\
\hline
\end{tabular}

Watson statistics. They became 2.16 and 1.92 respectively. ${ }^{12}$ The adjusted $R^{2}$ values were reduced to 0.3686 and 0.4059 . Both Durbin-Watson statistics reject the null hypothesis of no autocorrelation at the $5 \%$ level. A common method of controlling for autoregression is using a 2 -stage least squares approach [74], [75]. In the first stage, the autoregressive structure in the residual is estimated using a model postulating that the autocorrelation has a single lag structure, specifically:

$$
\epsilon_{i}=\rho * \epsilon_{i-1}
$$

where $\epsilon_{i}$ is the ith residual from the initial regression. The first stage allows us to find an estimate of $\rho, \hat{\rho}$ using a least-squares model. In stage $2, \hat{\rho}$ is used to remove the autocorrelation in the variables. Each variable, represented as $V A R$ in the next equation, is then adjusted to create a new variable, $\operatorname{adj} V A R$, using the formula:

$$
\operatorname{adj} V A R_{i-1}=V A R_{i}-\hat{\rho} V A R_{i-1}
$$

Since we are analyzing panel data with both time and country dimensions, implementation of the autocorrelation was applied at the country level using different estimates of $\rho$ for the Internet and cell phone regressions. Carrying this out on the differenced data increased the Durbin-Watson statistics to 2.24 and 2.18, and autocorrelation is still detected by this test at the $5 \%$ level. The adjusted $R^{2}$ statistics were 0.4292 and 0.3599 . This was our final model analyzed in the following section. Since autocorrelation has not been eradicated from the data we interpret our results cautiously and look for corroboration.

\section{RESULTS AND FINDINGS}

We used the $R$ statistical package to estimate these models (version 2.7.2) [71]. The complete set of code and data used in this study can be found at http://www.stodden.net/ICTD.

Tables I and II present summary statistics of the dependent variables (Internet and cell phone use per 100 country inhabitants) and the World Bank metrics for the countries in 2000 and 2006 respectively.

\footnotetext{
${ }^{12}$ Testing the residuals for autocorrelation using the Durbin-Watson test is the typical procedure, when the sample is large. It is also possible to test for cointegration: whether the combination of time series is stationary. See [72] and [73].
}

TABLE II

SUMMARY STATISTICS FOR 2006 DATA

\begin{tabular}{|lrrl|}
\hline Variable & Mean & Min & Max \\
\hline Internet Use per 100 & 21.66 & 0.03 & 92.52 \\
Cell Use per 100 & 53.19 & 0.42 & 138.06 \\
\hline Rule of Law & -0.07 & -2.00 & 2.03 \\
Voice \& Accountability & -0.07 & -2.28 & 1.72 \\
Political Stability & -0.08 & -2.31 & 1.60 \\
\hline GDP (PPP per capita) & $12,147.70$ & 195.43 & $76,537.15$ \\
POP (millions) & 35.67 & 0.051 & 1314.48 \\
Gender Ratio (M/F) & 100.4 & 84.3 & 218.5 \\
\hline
\end{tabular}

TABLE III

REGRESSION COEFFICIENT ESTIMATES FOR GLOBAL INTERNET PENETRATION

\begin{tabular}{|lrrl|}
\hline Variable & Estimate & Standard Error & p-value \\
\hline Rule of Law & 0.9018 & 1.1193 & 0.4207 \\
Voice \& Accountability & 0.9122 & 0.8514 & 0.2844 \\
Political Stability & -0.3783 & 0.5345 & 0.4793 \\
GDP & 0.0004 & 0.0002 & $0.0972^{*}$ \\
POP & -0.0488 & 0.8123 & 0.9521 \\
Gender Ratio & 0.8212 & 0.9189 & 0.3718 \\
\hline
\end{tabular}

\section{A. Modeling Global ICT Penetration as a Function of Demo- cratic Tendency}

We estimated two panel regressions of ICT penetration with controls for autocorrelation as discussed in the preceding section (differencing and the Durbin-Watson correction). Internet and cell phone use were modeled as functions of demographic variables along with control variables:

$$
\begin{gathered}
\Delta \text { Internet }_{i t}=\beta_{0}^{\prime}+\beta_{1}^{\prime} \Delta R L_{i t}+\beta_{2}^{\prime} \Delta V A_{i t}+\beta_{3}^{\prime} \Delta P S_{i t}+ \\
\beta_{4}^{\prime} \Delta P O P_{i t}+\beta_{5}^{\prime} \Delta G D P_{i t}+\beta_{6}^{\prime} \Delta M F_{i t}+ \\
\gamma_{t}^{\prime} T D+\xi_{i}^{\prime} C D+\epsilon_{i t} \\
i=1, \ldots, N, t=2, \ldots, T .
\end{gathered}
$$

The regression coefficients for Internet penetration are given in Table III. The coefficients on the individual country and time dummy variables are not included for space reasons. ${ }^{13}$ The most significant coefficient was GDP, and none of the democratic measures were significant. The positive coefficient on GDP confirms our intuition that wealthier countries have higher levels of Internet use.

The same regression was run for cell phone penetration, and the coefficient estimates are presented in Table IV. Cell phone use appears not to associated with wealth as Internet use is, and the male to female gender ratio in the country is strongly associated with increases in cell phone use, as is the level of political stability.

The influence of the gender ratio may be driven by outlier countries: Most countries had a male/female gender ratio of a little less than 100 , implying slightly more females than males in the population. The coefficient of 4.88 implies that

\footnotetext{
${ }^{13}$ The complete regression results can be found online at http://www. stodden.net/ICTD.
} 
TABLE IV

Regression Coefficient Estimates for Global Cell Phone PENETRATION

\begin{tabular}{|lrrl|}
\hline Variable & Estimate & Standard Error & p-value \\
\hline Rule of Law & -1.4120 & 2.0333 & 0.4876 \\
Voice \& Accountability & -2.458 & 1.5946 & 0.1236 \\
Political Stability & 2.2823 & 1.0044 & $0.0233 * *$ \\
GDP & -0.0002 & 0.0005 & 0.7061 \\
POP & 0.1225 & 1.4327 & 0.9319 \\
Gender Ratio & 4.8839 & 1.7342 & $0.0050^{* * *}$ \\
\hline
\end{tabular}

TABLE V

Top 10 MALE/FEMALE RATios, 2000 AND 2006

\begin{tabular}{|c|ll||ll|}
\hline Rank & Country & 2000 & Country & 2006 \\
\hline 1 & United Arab Emirates & 212.3 & United Arab Emirates & 218.5 \\
2 & Qatar & 198.1 & Qatar & 202.5 \\
3 & Kuwait & 150.3 & Kuwait & 152.3 \\
4 & Oman & 131.3 & Maldives & 127.3 \\
5 & Bahrain & 129.9 & Bahrain & 126.7 \\
6 & Saudi Arabia & 125 & Oman & 124.7 \\
7 & Maldives & 117.3 & Saudi Arabia & 120.5 \\
8 & Bhutan & 112.3 & Bhutan & 111.0 \\
9 & Jordan & 109.9 & Jordan & 110.2 \\
10 & Djibouti & 107.1 & Grenada & 108.1 \\
\hline
\end{tabular}

as the gender ratio increases by about 5 , cell phone usage per 100 inhabitants will increase by one phone. Throughout the years studied, roughly 7 of the 10 countries with the highest male/female ratio each year were located in the middle east, and the ratios at that end of the distribution dwarfed the other countries'. As displayed in Table VI, it is plausible some of these values are extreme enough to have a large impact on the regression fit, although why this did not occur in the internet regression is not clear. It is also possible the very high gender ratio values represent a 'middle east effect' since a number of those countries are highly represented in the top 10 gender ratio values. This implies that the coefficient on the gender ratio variable could represent a high growth in cell phone use in the middle east. Table VII gives the 2000 and 2006 cell phone data for these countries. The coefficient indicates that as the rate of change in the proportion of men increases, so does the rate of change in cell phone use.

Interestingly, the greater political stability and the lower the perceived threat of violence, the greater cell phone penetration. This may represent infrastructural stability if associated with political stability and thus a measure of investor's confidence. It is not clear why this factor would not therefore also be associated with an increase in Internet use. Perhaps cell phones are easier to proliferate than access to the Internet and so a smaller increase in political stability encourages cell phone increase before Internet increase.

As shown in Tables I and II, the average cell phone penetration in 2000 was about 16 phones per 100 inhabitants and in 2006 it was about 53, nearly a three-fold increase. This is a high rate of increase but, notably, the countries listed in Table VI (those with the highest male to female gender ratios) had much higher than average growth in cell phone penetration. This is quantified in the significant coefficient in the regression in Table IV, while allowing for the included
TABLE VI

Cell Phone Use Per 100 Inhabitants For Higher Gender Ratio COUNTRIES, 2000 AND 2006

\begin{tabular}{|c|ll||ll|}
\hline Rank & Country & 2000 & Country & 2006 \\
\hline 1 & United Arab Emirates & 43.98 & United Arab Emirates & 118.51 \\
2 & Qatar & 19.90 & Qatar & 109.6 \\
3 & Kuwait & 21.74 & Kuwait & 91.49 \\
4 & Oman & 6.63 & Maldives & 87.88 \\
5 & Bahrain & 30.61 & Bahrain & 122.88 \\
6 & Saudi Arabia & 6.40 & Oman & 69.59 \\
7 & Maldives & 2.83 & Saudi Arabia & 78.05 \\
8 & Bhutan & 0 & Bhutan & 9.77 \\
9 & Jordan & 7.72 & Jordan & 74.4 \\
10 & Djibouti & 0.04 & Grenada & 44.59 \\
\hline
\end{tabular}

confounding factors.

The World Bank measure for political stability is also significantly positively correlated with increased cell phone use. This finding suggests that political instability is related to the mass diffusion of cell phone usage. In other words, an increase in cell phone availability could increase the perceived likelihood that the government will be destabilized or overthrown by unconstitutional or violent means. In their statistical analysis, Mansfield and Snyder find that the process of democratization itself is indeed a destabilizing one [76]. "Certainly, the virtues of working democratic structures do not translate into a carefree path to the stabilization of democracy" [77]. This finding also supports the arguments presented by Rosenau and Johnson, as well as Shirky, who opine that the Internet can be used as a tool by civil society to organize collectively to effect political change [25], [78].

\section{B. Modeling ICT Penetration as a Function of Democratic Tendency Among the Most and Least Affluent Countries}

Examining ICT penetration for different strata of wealth may help isolate effects that are characteristic of those groups. Since wealth is a driver of investment one would expect GDP to play a role in the country's readiness and ability to adopt new communication technologies [79], [80], [81]. As established in the literature we also found increases in GDP to be associated with increases in Internet use. We choose to examine ICT penetration in both the top and bottom $20 \%$ of countries by 2006 GDP more closely. Our focus on these groups, in particular the bottom quintile, is driven by Mansfield and Snyder's work theorizing the instability of emergent and transitional regimes and the existence of the global digital divide [82].

Table VII lists the countries that fall into each of these groups.

As in the previous section we fit a model with an ICT penetration measure as the explanatory variable, and measures of democratic tendency and controls as independent variables for a panel regression over years 2000 to 2006. For the top wealthiest quintile of countries our model did not yield statistically significant results for Internet penetration. Table VIII gives the coefficient estimates. Since these countries are exceptionally wealthy and relatively stable politically it may not be a surprise that GDP is not a driver of Internet use, and 
TABLE VII

TOP AND BoTTOM 20\% OF COUNTRIES BY GDP IN 2006

\begin{tabular}{|l|l|}
\hline Top 20\% Countries & Bottom 20\% Countries \\
\hline Qatar & Zimbabwe \\
Luxembourg & Congo (Dem. Rep.) \\
Brunei Darussalam & Liberia \\
Norway & Burundi \\
Singapore & Guinea-Bissau \\
United States & Afghanistan \\
Ireland & Sierra Leone \\
Switzerland & Niger \\
Hong Kong, China & Central African Rep. \\
Kuwait & Ethiopia \\
Iceland & Malawi \\
Canada & Eritrea \\
Netherlands & Mozambique \\
Austria & Togo \\
Denmark & Rwanda \\
United Arab Emirates & Uganda \\
Sweden & Myanmar \\
Australia & Mali \\
Belgium & Madagascar \\
United Kingdom & Guinea \\
Finland & Comoros \\
Germany & Tanzania \\
Japan & Nepal \\
France & Burkina Faso \\
Bahrain & Lesotho \\
Italy & Bangladesh \\
Spain & Gambia \\
Taiwan, China & Haiti \\
Greece & Zambia \\
Cyprus & Ghana \\
New Zealand & Sao Tomé \& Principe \\
Slovenia & Benin \\
Israel & Kenya \\
Bahamas & Camegal \\
Korea (Rep.) & Chad \\
Saudi Arabia & \\
Czech Republic & dvoire \\
\hline & \\
\hline
\end{tabular}

TABLE VIII

InTERnet PENETRATION, TOP 20\% OF GDP (2006)

\begin{tabular}{|lrrl|}
\hline Variable & Coefficient & Standard Error & p-value \\
\hline Rule of Law & -0.3709 & 5.4055 & 0.945 \\
Voice \& Accountability & 4.771 & 4.0981 & 0.246 \\
Political Stability & -1.0344 & 2.2760 & 0.650 \\
GDP & 0.0003 & 0.0004 & 0.450 \\
POP & 1.6791 & 5.5724 & 0.764 \\
Gender Ratio & -1.7979 & 3.7568 & 0.633 \\
\hline
\end{tabular}

nor are the measures of democratic tendency, even though our subsets contains countries with varying levels of autocratic control.

Among the least wealthy quintile we fit the same panel regression model as above. Table IX gives the regression coefficient estimates. Our predictors did not yield highly significant coefficient estimates with the exception of the World Bank voice and Accountability metric. Voice and Accountability is negatively correlated with Internet penetration: implying that when countries notch up in the Voice and Accountability ranking, the use of the Internet increases. This seemingly paradoxical finding may be explained when note that our analysis is restricted the the lowest quintile of country in wealth. These countries experience disproportionately greater
TABLE IX

Internet Penetration, Bottom 20\% of GDP (2006)

\begin{tabular}{|lrrl|}
\hline Variable & Coefficient & Standard Error & p-value \\
\hline Rule of Law & 0.3702 & 0.4081 & 0.3660 \\
Voice \& Accountability & -0.8115 & 0.3656 & $0.0281^{* *}$ \\
Political Stability & -0.2583 & 0.1822 & 0.1585 \\
GDP & -0.0002 & 0.0014 & 0.9053 \\
POP & -0.0309 & 0.2784 & 0.9117 \\
Gender Ratio & 0.4026 & 0.3235 & 0.2155 \\
\hline
\end{tabular}

TABLE $\mathrm{X}$

Cell Phone Penetration, Top 20\% of GDP (2006)

\begin{tabular}{|lrrl|}
\hline Variable & Coefficient & Standard Error & p-value \\
\hline Rule of Law & 2.354 & 6.161 & 0.7029 \\
Voice \& Accountability & 4.012 & 4.736 & 0.3984 \\
Political Stability & 5.071 & 1.887 & $0.0612 *$ \\
GDP & -0.0008 & 0.0005 & 0.1071 \\
POP & -2.896 & 6.483 & 0.6558 \\
Gender Ratio & 2.8300 & 4.3690 & 0.5182 \\
\hline
\end{tabular}

political turmoil and it may be the case that countries with higher Voice and Accountability rankings have been reluctant to permit the growth of the Internet in their milieu.

Table $\mathrm{X}$ gives the coefficient estimates from the panel regression for cell phone penetration for the top $20 \%$ of wealthiest countries. There is a statistically significant effect in the World Bank metric of Political Stability: greater Political Stability is associated with an increase in cell phone use per inhabitant. This result seems intuitive as political stability is historically associated with greater investment in communications infrastructure and is consistent with our earlier regression on cell phone use. This suggests the wealthiest countries may be driving the correlation between political stability and cell phone penetration. None of the other variables were found to have a statistically significant relationship with cell phone penetration in the wealthiest countries.

Among the poorest countries, growth in Voice and Accountability had a statistically significant negative effect on growth in cell phone penetration. Although consistent with the Internet penetration regression results for this group of countries, the paradox remains as to the increase in per capita cell phone use as Voice and Accountability decreases. It is plausible citizens desire newer forms of ICT when Voice and Accountability is restricted. Another explanation may be that although not all countries in the bottom quintile are autocratic, a significant proportion are and cell phone use may facilitate the mobilization, organization and coordination of resistance against autocratic rule. Interestingly, the voice and accountability metric is not a significant predictor globally, yet is significant for types of ICT among the poorest countries.

\section{CONClusions And Future RESEARCH}

This paper is the first to our knowledge that uses recent Internet and cell phone use data in an empirical study of their relationship to democratic tendency. Previous studies uses measures of Internet use that ended in 1993 [26], [38]. Best and Wade's data reached only to 2002. This paper is also the first to the best of our knowledge that measures ICT diffusion 
TABLE XI

Cell Phone Penetration, Bottom 20\% of GDP (2006)

\begin{tabular}{|lrrl|}
\hline Variable & Coefficient & Standard Error & $\mathrm{p}$-value \\
\hline Rule of Law & 0.3938 & 0.4004 & 0.3271 \\
Voice \& Accountability & -0.8455 & 0.3733 & $0.0251^{* *}$ \\
Political Stability & -0.2776 & 0.1771 & 0.1193 \\
GDP & -0.0002 & 0.0014 & 0.9000 \\
POP & -0.0468 & 0.2815 & 0.8683 \\
Gender Ratio & 0.3913 & 0.3251 & 0.2308 \\
\hline
\end{tabular}

as a function of democratic indicators. Previous research has focused on whether ICT use predicts democratic measures.

These results support Bimbers assertions that the structure of political power has not been revolutionized or transformed into a new epoch of democracy [12]. Evidence can be found for both the populist thread in the literature and the notion that ICTs may act as an extension of the ruling class.

We found a statistically significant positive relationship between the rate of diffusion of the cell phone and the World Bank's "Political Stability" measure capturing perceptions regarding the likelihood that a government will be destabilized or overthrown by unconstitutional or violent means. Political Stability continues to have a significant positive relationship with the rate of cell phone use among the most affluent $20 \%$ of countries, but that relationship does not hold among the wealthiest countries. The "Voice and Accountability" indicator which measures perceptions of the extent to which citizens are able to participate in selecting their government, as well as freedom of expression, association and of the media, was a significant negative predictor of the rate of cell and Internet diffusion among the poorest quintile of countries. The diffusion of ICT access did not have any significant influence on "Rule of Law" while the increasing availability of cell phones were shown to have no influence on any of the three World Bank indicators.

Recall that the Rule of Law metric measures perceptions of the extent to which individuals have confidence in and abide by the rules of society-in particular the quality of contract enforcement, property rights, the police, and the courts as well as the likelihood of crime and violence. This measure was originally included in the analysis based on Diamond's research on the characteristics of democracy. However, the findings here suggest that the increase in "Rule of Law" perceptions does not influence ICT penetration, either positively or negatively. In other words, perceptions regarding the "Rule of Law" may be framed and influenced by factors other than widespread ICT use.

The populist school of thought believes ICT diffusion will decentralize access to communication and information while increasing citizen access [12], while Hill and Hughes claim that perhaps the Internet will bring about "a wider democratic revolution in the world" [22]. In our modeling Internet diffusion was not predicted by our measures of democracy, implying this revolution has not yet arrived. The rate of cell phone diffusion was predicted by higher rates of the "Political Stability" metric. Recall that cell phone are much more widely used globally than the Internet, so this may be a function of cell technology's earlier foothold than the Internet's. As Internet diffusion catches up to that of cell phone, the democratic metrics may be found to be predictors of this diffusion. This is not necessarily inconsistent with the populist thread in the literature as, according to Bimber, other scholars believe that the Internet may have a "transformative potential" because of the "one-to-one interaction among citizens and between citizens and government" it creates [12].

A paradox is created for the populist school in the finding that "Voice and Accountability" is negatively correlated with cell phone diffusion. This can be interpreted in favor of the argument that ICT diffusion can be centralized by government turning them into social control mechanisms [43]. As the rate of Voice and Accountability increases, the rate of diffusion of ICTs decreases among the poorest and least developed countries. Rates of cell phone use increase globally with decreases in political stability, lending further support to the thesis of ICTs as an extension of ruling class control.

This paradox may be resolved is we consider Page's view in 1995, that ICT diffusion may be still too nascent and insufficient to generate a well functioning system of political communication and deliberation [48]. It appears we are still too early to expect a close relationship between a vibrant public sphere and ICTs globally. As Bimber states, the "central theoretical problem for the populist claim is the absence of a clear link between increases in information and increases in popular political action" [12]. This paper provides evidence of the existence of this problem and the need to develop our understanding of this dynamic further.

It would be interesting to tie this research more closely to development, in line with Sen's reasoning that "Developing and strengthening a democratic system is an essential component of the process of development," could extend the empirical analysis in a fruitful direction. This might mean specifically testing whether the order in which political and civil rights are extended as a country emerges from an autocracy affects the rate of development. This could provide a setting in which to test the "Lee Thesis," that political rights should be withheld until economic development is achieved.

It may be valuable to explore empirical issues further. Modeling the autocorrelation structure with more than one lag may help reduce autocorrelation. It would also be interesting to test for cointegration among these variables. Certainly documented feedback loops exist between our independent variables, such as GDP and measures of democracy, and taking this explicitly into account may improve the modeling [83], [26]. It is also plausible that feedback loops exist between ICTs and democratic measures and future modeling could accommodate this. Further research into the modeling aspects could estimate models including variables that control for the different manifestations of cell phone and Internet use in different countries. A more comprehensive model might explore possible non-linearities: whether countries with low ICT adoption rates have different patterns of democratic tendency than those with high adoption rates. 


\section{ACKNOWLEDGMENT}

The authors would like to thank Michael Best and Colin Maclay for helpful discussion and the anonymous reviewers for constructive criticism. Sadia Ahsanuddin and Kristen Lovin provided outstanding research assistance.

\section{REFERENCES}

[1] M. Best and K. Wade, "The internet and democracy: Global catalyst or democratic dud?" June 2006, sam Nunn School of International Affairs.

[2] B. Barber, "Three scenarios for the future of technology and strong democracy," Political Science Quarterly, vol. 113, no. 41573-589, 1999.

[3] P. Schmitter and T. Karl, "What democracy is ... and is not," Journal of Democracy, vol. 2, no. 3, 1991.

[4] P. Norris, "Political protest in fragile states," July 2006, international Political Science Association World Congress.

[5] F. Zakaria, "The rise of illiberal democracies," Foreign Affairs, November 1997.

[6] Huber, D. Rueschemeyer, and J. Stephens, "The impact of economic development on democracy," Journal of Economic Perspectives, vol. 7, no. 3, pp. 71-85, 1993.

[7] E. Zuckerman, "Draft paper on mobile phones and activism," 2007. [Online]. Available: http://www.ethanzuckerman.com/blog/2007/04/09/ draft-paper-on-mobile-phones-and-activism/

[8] D. Kidd, Indymedia.org: a new communications commons. Routledge, 2003, pp. 47-69.

[9] A. Scott and J. Street, "From media politics to e-protest," Information, Communication and Society, vol. 3, no. 2, pp. 215-40, 2000.

[10] S. Andrew, "The control revolution: How the internet is putting individuals in charge and changing the world," The Century Foundation, Tech. Rep., 2000.

[11] R. Clarke, "Information technology: Weapon of authoritarianism or tool of democracy?" August 1994, iFIP World Congress.

[12] B. Bimber, "The internet and political mobilization - research note on the 1996 election season," Social Science Computer Review, vol. 16, no. 4, pp. 391-401, 1998

[13] R. Dahl, Democracy and its Critics. New Haven, CT: Yale University, 1989.

[14] H. Rheingold, Virtual Reality. New York, NY: Summit Books, 1991.

[15] R. Anderson, T. Bikson, S. Law, and B. Mitchell, "Universal access to e-mail: Feasibility and societal implications," RAND, Tech. Rep., 1995

[16] A. Etzioni, The Spirit of Community: Rights, Responsibilities, and the Communitarian Agenda. New York, NY: Crown Publishers, 1993.

[17] J. Pavlik, New Media Technology: Cultural and Commercial Perspective. Boston, MA: Allyn and Bacon, 1996.

[18] L. Grossman, The Electronic Republic. New York: Viking, 1995.

[19] G. Browning, Electronic Democracy: Using the Internet to Influence Politics. Wilton, CT: Online Inc., 1996.

[20] N. Negroponte, Being Digital. New York, NY: Vintage, 1995.

[21] J. Snider, "New media: Potential information and democratic accountability: A case study of governmental access community media," August 1996, american Political Science Association Convention.

[22] K. Hill and J. Hughes, "Computer mediated political communication: The usenet and political communities," Political Communication, vol. 14, pp. 3-27, 1999.

[23] A. Corrado and C. Firestone, Elections in Cyberspace: Toward a New Era in American Politics, A. Corrado and C. Firestone, Eds. Washington, DC: Aspen Institute, 1996.

[24] C. Steele and A. Stein, Communications revolutions and international politics. Albany, NY: State University of New York Press, 2002.

[25] J. Rosenau and D. Johnson, Information technology and turbulence in world politics. State University of New York Press, 2002.

[26] C. Kedzie, "Communication and democracy: Coincident revolutions and the emergent dictator's dilemma," RAND, Tech. Rep., 1997. [Online]. Available: http://www.rand.org/publications/RGSD/RGSD127

[27] S. Lipset, "Some social requisites of democracy: Economic development and political legitimacy," American Political Science Review, vol. 53, pp. 69-105, 1959.

[28] R. Jackman, "On the relation of economic development to democratic performance," American Journal of Political Science, vol. 17, pp. 61121, 1973.

[29] K. Bollen, "Political democracy and the timing of development," American Social Review, vol. 44, pp. 572-87, 1979.
[30] R. Burkhard and M. Lewis-Beck, "Comparative democracy: the economic development thesis," American Political Science Review, vol. 88, pp. 903-10, 1994

[31] J. Longdregan and K. Poole, "Poverty, the coup trap, and the seizure of executive power," World Politics, vol. 42, pp. 151-83, 1990.

[32] _ "Does high income promote democracy?" World Politics, vol. 49, pp. 1-30, 1996.

[33] B. Geddes, "What do we know about democratization after twenty years?" Annual Review of Political Science, vol. 2, pp. 115-44, 1999.

[34] F. Webster, Globalization, information and change. State University of New York Press, 2002.

[35] R. Reich, The Work of Nations: Preparing ourselves for 21st century capitalism. Vintage, 1992.

[36] T. Friedman, The Lexus and the Olive Tree: Understanding Globalization. Anchor, 1999.

[37] L. Waverman, M. Meschi, and M. Fuss, "The impact of telecoms on economic growth in developing countries," Centre for Economic Policy Research, Tech. Rep., March 2005.

[38] D. Richards, Making the national international: Information technology and government respect for human rights. Albany, NY: State University of New York Press, 2002.

[39] D. Barney, Prometheus Wired: The Hope for Democracy in the Age of Network Technology. University of Chicago Press, 2000.

[40] A. Mazrui and R. Ostergard, Technology transfer in the computer age: The African experience. State University of New York Press, 2002.

[41] D. Strienstra, Gender, women's organizing, and the Internet. Albany, NY: State University of New York Press, 2002.

[42] S. Kalathil and T. Boas, Open Networks, Closed Regimes. Carnegie Endowment for International Peace., 2003.

[43] W. Neuman, The future of the mass audience. Cambridge University Press, 1991

[44] T. Eyck, "Does information matter? a research note on information technologies and political protest," Social Science Journal, vol. 38, pp. 147-160, 2001

[45] N. Postman, Amusing ourselves to death. New York, NY: Vintage Books, 1985.

[46] H. Schiller, Culture Inc. Oxford University Press, 1989.

[47] W. Lippmann, Public Opinion. New York, NY: Macmillan, 1934.

[48] Page, Who Deliberates? Mass Media in Modern Democracy. Chicago, IL: University of Chicago Press, 1996.

[49] G. Cherian, "The limits of singapore's 'light touch' web regulation," 2008, politics 2.0 International Conference.

[50] R. Deibert, J. Palfrey, R. Rohozinski, and J. Zittrain, Access Denied: The Practice and Policy of Global Internet Filtering. The MIT Press, 2008.

[51] S. Oats, "Internet and democracy in russia," April 2008, politics 2.0 International Conference.

[52] R. Singel, "Seeking tighter censorship, repressive states target web 2.0 apps," Wired Magazine, March 2008. [Online]. Available: http://blog.wired.com/business/2008/03/etech-what-happ.html

[53] J. Zittrain, The Future of the Internet-And How to Stop It. Yale University Press, 2008.

[54] S. Mydans, "Myanmar junta unplugs internet," The International Herald Tribune, October 2003. [Online]. Available: http://www.iht.com/ articles/2007/10/04/asia/04info.php

[55] J. Goldsmith and T. Wu, Who Controls the Internet? Illusions of a Borderless World. Oxford University Press, 2006.

[56] L. Lessig, Code: Version 2.0. Basic Books, 2006.

[57] D. Drezner, "The internet's effect on state-society relations," March 2006, international Studies Association Convention.

[58] T. Price, Cyber Activism: Advocacy Groups and the Internet. Washington, DC: Foundation for Public Affairs, 2000.

[59] J. Goldsmith, "Regulation of the internet: Three persistent fallacies," Chicago-Kent Law Review, vol. 73, December 1998.

[60] R. Beilock and D. Dimitrova, "An exploratory model of inter-country internet diffusion," Telecommunications Policy, vol. 27, pp. 237-252, 2003.

[61] B. Mesquita and G. Downs, "Development and democracy," Foreign Affairs, September 2005.

[62] D. Scheufele and M. Nisbet, "Being a citizen online: New opportunities and dead ends," The Harvard International Journal of Press/Politics, vol. 7, no. 3, pp. 55-75, 2002.

[63] H. Milner, "The digital divide: The role of political institutions in technology diffusion,” August 2003, american Political Science Association. 
[64] L. Diamond, "elections without democracy: Thinking about hybrid regimes," Journal of Democracy, vol. 13, no. 2, April 2002.

[65] - Developing Democracy: Toward Consolidation. John Hopkins University Press, 1999.

[66] D. Kaufmann, A. Kraay, and M. Mastruzzi, "Governance matters vii: Aggregate and individual governance indicators 1996-2007," World Bank, Tech. Rep., 2007.

[67] A. Sen, Development as Freedom. Oxford University Press, 2001.

[68] “Opennet initiative." [Online]. Available: http://opennet.net/

[69] R. Faris and N. Villeneuve, Access Denied: The Practice and Policy of Global Internet Filtering. MIT Press, 2008, ch. 1.

[70] C. Granger and P. Newbold, "Spurious regressions in econometrics," Journal of Econometrics, vol. 2, pp. 111-120, 1974.

[71] "R." [Online]. Available: http://www.r-project.org/

[72] C. Granger, "Some properties of time series data and their use in econometric model specification," Journal of Econometrics, vol. 16, pp. 121-130, 1981.

[73] _ "Co-integration and error correction: Representation, estimation and testing," Econometrica, vol. 2, pp. 251-176, 1987.

[74] T. Amemiya, "The nonlinear two-stage least squares estimator," Journal of Econometrics, vol. 2, pp. 105-110, 1974.

[75] R. Cumby, J. Huizinga, and M. Obstfeld, "Two-step two-stage least squares estimation in models with rational expectations," Journal of Econometrics, vol. 21, pp. 333-355, 1983.
[76] E. Mansfield and J. Snyder, "Conceptualizing and measuring democracy:evaluating alternative indices," International Organization, vol. 56, no. 2, pp. 297-337, 2001.

[77] H. Barnes, "The contribution of democracy to rebuilding postconflict societies," The American Journal of International Law, vol. 95, no. 1, pp. 86-101, 2001.

[78] C. Shirky, Here Comes Everybody: The Power of Organizing without Organizations. Penguin Press, 2008.

[79] C. Argevou, "Ols bias in a nonstationary autoregression," Information Technology for Development, vol. 8, no. 1, pp. 15-28, 1998.

[80] B. Oyelaran-Oyeyinka and K. Lai, "Internet diffusion in sub-saharn africa: A cross-country analysis," Telecommunication Policy, vol. 8, no. 1, pp. 507-527, 1998.

[81] J. Gibbs, K. Kraemer, and J. Dedrick, "Environment and policy factors shaping global e-commerce diffusion: A cross country comparison," The Information Society, vol. 19, no. 1, pp. 5-18, 1993.

[82] N. Kshetri and N. Dholakia, ENCYCLOPEDIA OF INFORMATION SCIENCE AND TECHNOLOGY, 2nd edition. Idea Group Publishing, 2008.

[83] P. Norris, Digital Divide: Civic Engagement, Information Poverty, and the Internet Worldwide. Cambridge University Press, 2001. 